\title{
Multinational Firm Growth and Sustainability Responses to Dynamics of Business Regulations in Host Market
}

\author{
Damto Basha Chewaka ${ }^{1,2, *(D)}$ and Changzheng Zhang ${ }^{1}$ \\ 1 Business School, Hohai University, Nanjing 211100, China; zcz@hhu.edu.cn \\ 2 Business and Economics College, Bule Hora University, Bule Hora 144, Ethiopia \\ * Correspondence: d20191306@hhu.edu.cn
}

check for updates

Citation: Chewaka, D.B.; Zhang, C. Multinational Firm Growth and Sustainability Responses to Dynamics of Business Regulations in Host Market. Sustainability 2021, 13, 13945. https://doi.org/10.3390/ su132413945

Academic Editors: Marek Durica,

Lucia Svabova, Jaroslav Frnda and Katarina Kramarova

Received: 5 December 2021

Accepted: 13 December 2021

Published: 17 December 2021

Publisher's Note: MDPI stays neutral with regard to jurisdictional claims in published maps and institutional affiliations.

Copyright: (c) 2021 by the authors. Licensee MDPI, Basel, Switzerland. This article is an open access article distributed under the terms and conditions of the Creative Commons Attribution (CC BY) license (https:// creativecommons.org/licenses/by/ $4.0 /)$.

\begin{abstract}
Dynamics in business regulations measured by ease of doing business is a new approach that indicates countries' business climate reforms toward suitability for investment growth. The present study took three variables from the ease of doing business data and evaluated them toward predictive power of FDI flow to 19 Sub-Saharan African countries by using fixed-effect model. Based on the analysis, the official time, procedures, costs, and minimum capitals in starting a business stage, enterprise registrations and official permissions of the firm establishment had a material effect on investment growth. Even though, on one side trade openness and the growing market size was seen as an opportunity, the deep-rooted corruption and landlocked was the trap for the smooth growth of firms in the region.
\end{abstract}

Keywords: ease of doing business; multinational firms' growth; official procedures; business regulations; official time; enterprise registrations; market size

\section{Introduction}

Attentions toward encouraging Multinational enterprises advancement across home and host economies are becoming the largest sources of economic stability and new technologies for countries in reference [1,2]. As cited in the findings by reference [3,4] in Modern FDI theory, many MNE's growths across borders are also contributing positively to the productivity, business techniques, and competitiveness of emerging firms in the least developed areas beyond the transfer of capital. However, in traditional FDI, it was the movement of capital and varies returns between countries. In the Neoclassical economics view, FDI started to respond to the living standard of society through openness to other country economies and enhancing economic growth. Although several spill-over effects follow the expansions of these MNEs' progress in the recent economic era, there are several obstacles besides their growth and expansions. Most of these factors were classical, country-specific and some are emerging along with firms' expansions. For instance, in Africa's context, several factors were argued by scholars as obstacles to smooth investment growth and expansions. For example, reference [5] argued that the low resource flexibility, deep-rooted corruption, business regulations irregularity, infrastructure barriers, and shortage of foreign currency were mentioned as the constraint to the low record of investment in the continent. In another study, reference [6] argued that the importance of clear knowledge about the factors that facilitate FDI flow in the region and beyond for policy implications. Likewise, the investigation by reference [7] also indicated that as there is an increasing interest in improving business regulations in Sub-Saharan African countries, the region needs further improvement in investment games flexibility from the rest of the developing regions to boost FDI. Moreover, the fragmented business regulations in the continent had brought to a low global share of FDI. In another dimension, the regional market size, trade openness, and landlocked countries were other sources of obstacles that challenged firms' positive growth and sustainability response in the region [6]. 
Similarly, as argued by reference [8] the bundles of opportunities such as low labor costs, availabilities of natural resources and growing market demand in a different country can change the wave of investment growth commitment by potential investors to stay in less developed areas. For instance, when investment locations are unsuitable regarding irregular business regulations, the investors prefer the option of location flexibility. With regards to the influence of location, real options theory argued two types of options. These were growth options and switching options. The first option is location flexibility from within the country, whereas the switching option is changing firm location from one country to another country [9]. This further implies that the areas suitable for ownership, locations, and internalizations are capable of receiving high inward FDI [10]. This links FDI to factors under considerations. Additionally, the locations with suitable technology and the growing market size have more power of accepting inward FDI [11].

In the present research, the role of business regulation reforms in SSA countries was emphasized. According to reference [12], Business regulations reform measured by World Bank ease of doing business is a new approach of measuring the degree of business regulations suitability for investors. However, due to the dominance of traditional FDI determinants, it's rarely implemented in studying investment growth and sustainability in the Africa continent, except by a few. For instance, reference [13-15] explored that the costs of doing business, lack of uninterrupted sources of energy (electricity), and highest taxes were identified as constraints of investing in Africa. In a similar manner, reference [16] argued that transportations infrastructure, telecommunications services, and the internet were expensive in the continent that exacerbates the distance in the markets, and influenced firm positive growth responses. Additionally, reference [17] argued that policy issuers need to be conscious and reemphasize corruptions eliminations against countries' resources. In another view [18] findings also indicated that efficient business regulations have a material effect on encouraging FDI flow across borders. In fact, the relationship of ease of doing business and Foreign Direct Investment flows rate was an overlocked aspect in the region. Specifically, 19 East African countries received the only US \$0.674 Billion on average of global FDI inflow share based on 15 years of data (2005-2019). Therefore, beyond classical FDI determinants "Does business regulations measured by ease of doing business have a significant effect on inward FDI in Sub-Saharan Africa countries" was the central question of the present research.

In order to address the designed question and to reach the hypothesis, the present research contented with introductions, Empirical and Theoretical foundations, Material and Methods, Empirical results and Discussions, Policy implications, Conclusions and Suggestions.

\section{Reviewing Literatures}

\subsection{Introducing Ease of Doing Business in Multinational Enterprises Growth Studies}

For achievability of rational investment decision, updated knowledge about the status of the Multinational business growth and factors that influence firms' growth such as business games are quite useful for policy issuers. Likewise, it is also essential to justify the mechanisms of Multinational business performance improvement realized by identifying its determinants. For instance, before the 1980's classical FDI determinants such as resources, low labor cost, exchange rates, and market access were more emphasized for a firm's productivity determinants. However, the influence of natures of business regulations on inward FDI has not emphasized rather the existence of market demand, resource availability (such as oil, natural gas, petroleum) [19], and labor intensiveness [20]. With regards to country market size, cross-border firms rely on growing countries' demand size. As demand size is deteriorating, Multinational firm sticks to the growing demand area. Similarly, the location with accumulated tangible and intangible resources has high opportunities for investment chances. In another perspective, low labor cost is another opportunity for labor-intensive firms. On top of each, firm efficiency in the host economy will be realized by effective business regulations to reap the intended profit. Thus, ac- 
cording to recent research such as [21,22] ease of doing business approach was introduced and evaluates the gaps of business rules relaxations such as regulations improvement or rigidity and suggests policy feedback for countries.

According to reference $[23,24]$, ease of doing business is an international report that indicates the extent of business climates in various countries, through quantitative and qualitative values. These results are representing the well-functionality of countries' institutions and their economic strengths. Moreover, Ease of Doing Business indicators are contented with two main components such as Ease of Doing Business Ranking and Ease of Doing Business scores. Each of them is constructed from 10 sub-components with the advantages of flashing lights on multiple variables at once that help multinational investment growth decision process. As cited by reference [21], the 10 doing business indicators further decomposed into the number of steps it required, number of working days, the number of official costs, and minimum capital required in starting a business, registrations of firms, and dealing with firm constructions permits. The finding by reference [25] also adds that the scores from each of doing business indicators are worthful credentials in multinational firms' growth and sustainability responses in addition to traditional FDI determinants. In a similar manner [26], cross-border investors prefer frontiers, a top-ranked and stable economy. In contrast, the countries with inefficient and irregular business regulation stifle international business performances [27]. In Sub-Saharan African countries context also, reference [28] argued that FDI inflow and business climate were correlated, whereas registering property and trading across borders were significantly associated with FDI. In order to realize responses of firms in the region market, we followed O-L-I paradigms with ease of doing business indicators and in predicting multinational business expansions. In this context, O-L-I simultaneously suitability with regards to three initial phases of ease of doing business such as starting a business, registration of property, and firm construction permits toward firms' expansion were discussed. Additionally, the decomposed cardinal variables such as official costs in US \$, official times in working days, official procedures in number and minimum capital contented in starting a business, registering of property, and constructions of firms were also considered. Moreover, by controlling the impacts of Market size and corruption perception index, the association of O-L-I and ease of doing business is also positive.

\subsection{OLI Paradigms in Context of Ease of Doing Business}

The Multinational Business studies toward consensus on specific FDI theories have been tried by several scholars. However, it is still never ended precisely. Among the first scholars, Hymer was at the forefront. Concerning the contributions, Hymer positioned the Firm-specific advantages of Multinational enterprises in offsetting the liability of foreignness while conducting a business abroad [29]. However, the premise was followed by many critics due to the market monopoly that discourages the power of the market demand and supply [30]. Following Hymer 1976, a new approach by reference [10] was introduced naming Eclectic Paradigms. According to reference [31], Eclectic theory had integrated three firm-specific advantages (Ownership, Location, and internalizations) in order to facilitate the flow of Multinational companies. Therefore, O-L-I paradigms (eclectic theory) assured that cross-border investment is possible abroad only when the existence of three distinct firm-specific advantages obtained by firms is confirmed simultaneously. However, high uncertainty raises the costs, time, procedures, minimum capital, and other factors required to undertake Multinational expansion overseas that make firm-specific advantages not easy to reap. In fact, success in international business needs inclusiveness of societal habits and cultural ingredients such as norms, beliefs, values, demographics, and the institutional environment of the receiving economy. Moreover, these factors could increase the complexity regarding where to invest (Location choice decision) and how to invest (Internalization) that further increasing the costs of doing business abroad.

Up to recent times, Eclectic theory is a frontline theory among FDI Theories. Due to its integrated approach [32], various theories such as international trade, imperfect markets, 
internationalization theories, and others were observed in it. Sequentially, to start FDI at the host country the firm needs to possess net ownership advantages $(\mathrm{O})$ over other firms serving particular markets first. The nature of possession includes coordination of activities and firm's institutions that are under the common governance with the hosting country government. Therefore, it takes several days, unnecessary delays, and long procedures to complete ownership of firm-specific advantage and to distinguish exclusive natures of new firm innovations to host economy over those of other countries in serving any market.

In another aspect, Location (L) specific advantages are the investor's ability to choose a value-adding destination [33]. For investment success, location advantages are at the core of the investment decision process and can be influenced by state policies. Likewise, the more a country's firms enjoy the suitable area and ownership advantages, the greater the incentive they have to internalize them. This shows, the more profitability and exploit ownership advantage outside the home country, the higher the probability of engaging in FDI by firms. In contrast, when the perceived benefit is less than the perceived cost, investors enforced to choose the country with low costs of investment. The simplest accessibility of information, easy bargaining, and easily accessible legal enforcement are the guaranties for the internalizations stage. When internalization leads to foreign investment the firm may incur political and commercial risks due to unfamiliarity with the foreign investment. In another way these are costs of doing business abroad, that may arise from the liability of foreignness. This is also the bridge that links FDI flow, doing business, and eclectic theory. Advancing to O-L-I implementation as FDI theory [31] introduced additional determinant "institutional dimension" to the theory.

From the perspectives of the combined effort of eclectic theory and ease of doing business indicators, when firms are comfortable in firm-specific advantages in ownership, locations, and internalization; it also implies that the suitability in procedures, time, cost, and minimum capital as constraints and vice versa. As mentioned earlier, as high uncertainty is attached to the Multinational firms' expansions, the real option embedded in the firm's decisions are mainly categorized as switching options and growth options. For instance, the Growth option is the decision when a high level of business regulations shocks to own, internalize, and location selection. In the growth option, factors such as the locations with high costs to operate a business, several days delay to begin new firms, long procedures to accomplish each task, high minimum capital at the initial, and complex legal frameworks are not easy to imitate. Therefore, holding another factor constant, the suitability of in OLI frame of Multinational business in starting a business stage, registering business and firms' construction permit can inspire firm to growth and sustainability at overseas and vice versa [10]. In contrast, unsuitable locations with regards to its business regulations harm multinational firms' growth options and inspire switching decisions to another country.

In another perspective, from real options theory ownership of firms' specific advantage of the multinational business is the factor that determines firms' growth or switching decision. Similarly, from the perspectives of Eclectic theory, the locations with suitable to own firm-specific advantage such as assets are ease for growth option. In this context, credentials such as costs, time, and procedures of owning firms' specific advantages are not complex. However, as the costs, time, and procedures in doing business are becoming complex it is not easy to imitate such business regulations by firms efficiently and effectively.

Moreover, for multinational firms' internalizations of firm-specific advantage is also crucial. However, internalizations of a firm's specific advantages are challenged by the highest costs to internalize, longer official procedures, and longer delay time to internalize. Thus, multinational businesses enforced to join/switch to the country with the suitable time, costs, and procedures [34-37]. As cited by reference [38], the high commitment of entry is positively associated with locating in strong economic, cultural, and historic linkages of new business [39-41]. 
For example, in addition to irregularity in business regulations, "costs of foreignness" are also another factor that foreign firms encounter in the host economy [42]. Indeed, in switching option decisions, Multinational enterprises face powerful uncertainty to obtain firm-specific advantages that increase the option to leave former countries or regions to new areas. Furthermore, [43] study indicated that enterprises should be aware of the effect of corruption in formulating business strategies that discourage foreign firm performances and enforce firms to switch to another country and may face it again. Moreover, limitations in firms' foreign market awareness due to psychic distance also inspires switching option. As cited by reference [44], the psychic distance that promotes switching is also contained factors that limit market information to foreign firms. In addition to this variety in language, education level, work habits, and cultures are also the issues that pave way for switching options [9]. Moreover, Eclectic theory by Dunning so far explained that investors prefer locations that have simple and achievable investment areas to avoid high costs of investment. In the work of reference [32] also Multinational enterprise movement is most of the time directed toward resources, growing market, suitable environment, and quality institutions [45,46].

\section{Methodology}

In the present explanatory research, we intended to examinations of the effect of some ease of doing business variables on Multinational business performances across countries by considering the controlling roles of country Market size and Corruption perception level. In order to realize that, this research adopted secondary data from World Bank and Transparency international web pages.

\subsection{Procedures}

In the present research, a panel of 15 years of data was gathered and used. First, some variables and countries with incomplete data during the period of 2005-2019 were removed. Then, 22 countries from East African of SSA in the analysis were included. Secondly, we considered an entry multinational business in the form of Foreign Direct Investment to 19 countries screened from the first step through assessing the data availability. Since the present work emphasized multinational business expansions in the form of FDI to 19 countries found in east African countries for 15 years, our data includes 285 observations $=19$ (Countries) $\times 15$ (Years). This database can also be understood as 15 years of longitudinal panel data for 15 years of investment growth in 19 Sub-Saharan African countries. Third, after the construction of 285 Multinational business reliant variables, then the roles of control variables were harmonized to each corresponding instance. Moreover, the variables used in the current study were as in Table 1.

Table 1. Variable and Description.

\begin{tabular}{|c|c|}
\hline Variable & Variable's Descriptions and Contents \\
\hline FDI flow to (East) SSA Counties & $\begin{array}{c}\text { Foreign direct investment, in percentage of GDP in US Dollar to SSA countries } \\
\text { from different countries }\end{array}$ \\
\hline (1) Starting a business score & Contains official Procedures, time, Cost and minimum capitals at starting \\
\hline (2) Trade openness & By GDP normalized sum of exports and imports \\
\hline (3) Registering Property scores & The procedures, time, and cost required to register enterprise' property \\
\hline (4) Procedures in number & $\begin{array}{l}\text { official procedures in starting a business, registrations and allow the } \\
\text { construction permit, excluding unofficial procedures. }\end{array}$ \\
\hline (5) Time in days & $\begin{array}{l}\text { officially recorded number of working days required in registration, start up } \\
\text { and firms' constructions dealing }\end{array}$ \\
\hline (6) Landlocked & Lack of water resources access as a means connecting countries \\
\hline (7) Dealing with establishment permit & The procedures, time, and cost required to register property \\
\hline (9) Minimum capital in US \$ & $\begin{array}{c}\text { Officially set minimum capitals in starting a business, Funds deposited in a } \\
\text { bank or with third party before registration. }\end{array}$ \\
\hline (10) Market size in real GDP & It about growth market regards to Real GDP per capita \\
\hline (11) Corruption Perception index (0-100) & Indicators of the levels of corruption perceptions levels in public offices \\
\hline
\end{tabular}




\subsection{Variables: Dependent, Independent and Controls}

In the present study, the dependent variable was the log of net FDI flow in billions of US dollars between 2005-2019 that covers before the sudden surge of the Covid19 pandemic crisis. Actually, some former researchers had used Multination's business expansions in the forms of net FDI as a dependent variable such as but not limited to references $[13,21,22,26,34]$ by associating FDI-Ease of doing business nexus approach but brought inconsistent findings. With a similar manner, such as few former studies such as references $[18,47,48]$ and others through embedding its innovative approach the independent variables for this research were ease of doing business indicators components such as starting a business, registrations multinational firms and dealing with multinational business establishment credentials as indicated in Table 1.

Additionally, in the present research four sets of control variables were introduced to minimize the endogeneity effects and to increase the estimation precision by minimizing the standard error. Procedurally, first variables related to the multinational business characteristics changes in host countries were observed, then determinants of multinational business growth such as the country market size, trade openness, and landlocked were used from country Macroeconomic sets of variables. For instance, in East African country's market size record, Ethiopia's Market size was above World Median from 2011-2017. However, from 19 East African country's comparative views from 2005-2019 Kenya, Ethiopia, Tanzania, Uganda, Mozambique, Madagascar, and Zambia were above the regional market size median, whereas the rest of the countries were below the regional median. Then, by controlling the effect of market size, landlocked, and trade openness, the effect of business regulations was evaluated at this stage.

By next, the present model evaluated the effect of ease of doing business toward firm growth and sustainability by further controlling the effect of corruption in public organizations. Indeed, corruption misleads Multinational business expansions behaviors. Additionally, Corruption rewards unproductive actions by encouraging unqualified aspects and rights to Multinational businesses in exchange for bribes, at the expense of qualified and innovative firms. Moreover, pervasive corruption weakens the legitimacy of leaders. According to transparency international, a 0-100-point scale is used, that the higher index value implies that the country has a clearer and no corruption in the public system, whereas zero values imply a high level of corruption by governing bodies.

\subsection{Concept Framing, Model Specifications, Validity Test and Analysis Approach}

In several previous FDI studies, almost traditional determinants were used. For instance, [7] argued that trade openness, institutional quality [49], and structural reform were factors that need to be considered to speedup of FDI flow to SSA. As cited by reference [16], Poor business regulation, pose a competitive burden on firms. Hence, rather than conceptualizing the full "business cycle concepts" such as in three phases (initial, operation, and at solvency) that argued by reference [34], the present research considered only the FDI inflow-Ease of doing business nexus approach by selecting three variables from ease of doing business indicators those against firms' performances at initial phases. The base for these three variables' selections was the number of costs, number of times in working days, official procedures needed were used as the common measurement in the three variables (Refer Table 1). These three variables include starting a business, dealing with firms' establishment's permits, and registering multinational business property. The concepts were drawn from but not limited to references [50-53].

According to reference [50,54], ease of doing business also indicates that the administrative burden that allows whether enterprises are easily imitating business regulations in the host economy. For instance, complex and rigid business regulations deter the wellfunctioning of firms, whereas market demand-based business regulations are suitable for new firms. Thus, we followed the way of evaluating the effect of business regulations measured by ease of doing business on Multinational businesses attracting and sustaining its achievement in 19 SSA countries. Indeed, MNEs prefer the countries contented with the 
shortest procedures to initiate investment, no or shortest delays time, affordable costs with suitable minimum capitals, and a clear legal frame. Therefore, the present model emphasis 19 SSA African country's ease of doing business employing World Bank doing business variables in a panel of Fixed effect Model. As a matter of fact, the frontiers economy dominates the chance of far to frontiers economy by relaxing their countries business regulations. Therefore, we deliberately emphasized on effects of business climates on Multinational business flows in East Africa, that certainty able to a robust economy of the region. Thus, the following are the hypothetical base of the study:

Hypothesis 1 (H1). Business regulations such as ease of starting a business score and its components (costs, time, procedures and minimum capital) have an association with ownership, locations and internalizations of firms.

Hypothesis 2 (H2). Trade openness have association with attracting inward FDI in SSA.

Hypothesis 3 (H3). Business regulations such as registering of property score and its components (costs, time, procedures) have an association with ownership, locations and internalizations of firms.

Hypothesis 4 (H4). Business regulations such as dealing with construction permit score and its components (costs, time, procedures) have an association with ownership, locations and internalizations of firm specific advantages.

Hypothesis 5 (H5). Landlocked nature of country have an effect on MNE's attractions to SSA.

Hypothesis 6 (H6). The interactions of starting a business score and Corruption perception index have an association with firms' response to growth.

Hypothesis 7 (H7). The interactions of Registering Property, Country Market Size and Corruption perception have an association with Firm attractions.

Hypothesis 8 (H8). The interactions of dealing with firm construction permit and corruption perception level have association with inward FDI.

From the hypotheses, in order to predict the effects of dynamics of business regulations on MNEs growth and sustainability response, the variables constructed into three groups (Equations (1)-(3)). Under Equation (1), we considered ease of starting a business and its components (time in numbers of working day, numbers of procedures, costs to be incurred and minimum capital). Additionally, Model 1 contained the moderating powers of corruption in public institutions toward inviting MNEs. Moreover, the interactions of starting a business and corruption in public organizations were examined in Equation (1).

$$
\begin{aligned}
& \text { FDI }_{(\mathrm{ij})}=f \text { (Starting a business, Time, Procedures, Market Size, Costs } \\
& \text { Corruption Perception index, Minimum Capital } \\
& \text { Starting a business * corruption level, landlocked) } \\
& \mathrm{Y}_{\mathrm{ij}}=\beta_{0}+{ }_{\beta 1} \mathrm{SB}_{\mathrm{ij}}+\beta_{2} \text { Time }_{\mathrm{ij}}+{ }_{\beta 3} \text { Costs }_{\mathrm{ij}}+{ }_{34} \mathrm{CPI}_{\mathrm{ij}}+{ }_{35} \text { Procedures }_{\mathrm{ij}} \\
& \beta 6 \text { landlocked }+{ }_{\beta 7} \text { Starting a business }{ }^{*} \text { Corruption level } \mathrm{ij}_{\mathrm{ij}}+\varepsilon_{\mathrm{ij}}
\end{aligned}
$$

Secondly, model two contained registering of property and its subcomponents such as time to register firms, costs it incurs, the number of procedures it took to register. Additionally, the predictive power of countries market size was evaluated in this model. The interaction of registering property with market size and corruption perception level together were also measured in Equation (2);

FDI $_{\text {flow }(i j)}=f$ (Registering Enterprise, Time, Procedures, Corruption Perception index,

Costs, corruption * registering property*Market size) 


$$
\begin{gathered}
\mathrm{Y}_{\mathrm{ij}}=\beta 0+\beta{ }_{38} \mathrm{RP}_{\mathrm{ij}}+{ }_{\beta 9} \mathrm{CPI}_{\mathrm{ij}}+\beta 10 \text { Time }_{\mathrm{ij}}+\beta 11 \operatorname{Costs}_{\mathrm{ij}}+\beta 12 \text { Procedures }_{\mathrm{ij}} \\
+\beta 13 \text { Corruption }^{*} \text { Market size }^{*} \text { registering property }_{\mathrm{ij}} \\
+\beta 14 \text { Trade openness }_{\mathrm{ij}}+\varepsilon_{\mathrm{ij}}
\end{gathered}
$$

Equation (3) contained dealing with establishment of MNEs and factors embedded in it, such as costs, time and procedures to realize establishment of fixed assets at overseas. Moreover, the interactions of dealing with MNEs establishment against firm growth and countries corruption levels were evaluated in Equation (3).

$$
\begin{gathered}
\text { FDI }_{(\mathrm{ij})}=f \text { (Time, Procedures, Dealing with construction permit, Costs }^{\text {Corruption Perception index })} \\
\mathrm{Y}_{(\mathrm{ij})}=\beta 0+\beta{ }_{15} \mathrm{DCP}_{\mathrm{ij}}+\beta_{16} \mathrm{CPI}_{\mathrm{ij}}+\beta 17 \text { Time }_{\mathrm{ij}}+\beta 18 \operatorname{Costs}_{\mathrm{ij}}+\beta{ }_{19} \text { Procedures }_{\mathrm{ij}}+\varepsilon_{\mathrm{ij}}
\end{gathered}
$$

where; FDI represents Foreign Direct Investment inflow to SSA countries from 2005 to 2019, $\beta_{0}$ represents the constant term, $\beta_{1}, \beta_{2}, 3 \ldots 12$ represents slope coefficients of ease of doing business and controlling variables as described in Table 1.

In the model quality test, according to [54-56], since ease of doing business data are country-level indicators such as GDP per capita, FDI inflows, and annual growth rates, then it contains multiple observations per country. Additionally, the potential confounding influence of unobserved heterogeneity due to country-level effects is also considered. Thus, we use the fixed effects regression method to alleviate heterogeneity concerns. According to [57], the fixed effects method is preferable to the random effect method when a dataset is generic and based on the Hausman test result $\left({ }^{* * *} p<0.01,{ }^{* *} p<0.05,{ }^{*} p<0.10\right)$. In order to avoid, the model suffering from serially correlated error terms that may include a result of serially correlated unobserved factors was checked by xtregar Stata command [58].

\section{Empirical Results and Discussions}

\subsection{Descriptive Results}

The ease of doing business is an aggregate amount constructed from different param-

\begin{tabular}{|c|c|c|c|c|c|c|c|c|c|c|c|c|c|c|}
\hline Variables & Mean & Std. Dev. & 1 & 2 & 3 & 4 & 5 & 6 & 7 & 8 & 9 & 10 & 11 & 12 \\
\hline Net FDI inflows & 0.674 & 0.142 & 1.00 & & & & & & & & & & & \\
\hline Starting a business & 40.61 & 37 & 0.73 & 1.00 & & & & & & & & & & \\
\hline Trade openness & 51.41 & 31.22 & 0.64 & 0.69 & 1.00 & & & & & & & & & \\
\hline Construction permit & 39.0 & 52 & 0.72 & 0.51 & 0.49 & 1.00 & & & & & & & & \\
\hline Registering Property & 51.0 & 8 & 0.26 & 0.05 & 0.42 & 0.78 & 1.00 & & & & & & & \\
\hline Time in days & 195 & 32 & 0.81 & 0.68 & 0.60 & -0.62 & 0.84 & 1.00 & & & & & & \\
\hline Landlocked & 0.75 & 0.12 & 0.31 & 0.22 & 0.43 & 0.27 & 0.45 & 0.61 & 1.00 & & & & & \\
\hline Costs in US \$ & 135.3 & 27 & 0.16 & 0.84 & 0.72 & 0.07 & 0.77 & 0.53 & 0.49 & 1.00 & & & & \\
\hline Procedures in no. & 8 & 6 & 0.42 & 0.93 & 0.49 & -0.19 & 0.63 & 0.90 & 0.49 & 0.57 & 1.00 & & & \\
\hline Minimum capital & 492.4 & 109 & 0.22 & 0.09 & 0.12 & -0.37 & 0.12 & -0.07 & 0.04 & 1.00 & 0.37 & 1.00 & & \\
\hline Market size & 24.3 & 9 & 0.36 & 0.54 & 0.47 & 0.23 & 0.49 & 0.59 & 0.31 & 0.19 & 1.00 & 0.56 & 1.00 & \\
\hline Corruption Perception & 31 & 4 & 0.80 & 0.83 & 0.55 & -0.14 & 0.76 & 0.85 & 0.86 & 0.20 & 0.04 & 0.36 & 0.71 & 1.00 \\
\hline
\end{tabular}
eters determining the degree of business regulations in countries. The values from the computations are worthful for investors' decisions at entry, at operation time, and exit times of the investors. Thus, the values in Table 2 also indicates that the positive association between the expansion of multinational enterprises and business regulations.

Table 2. Correlation result and Descriptive statistical values.

The result in Table 2 also revealed that the mean values of inward FDI indicated that there were about US $\$ 0.674$ billion over 15 years to SSA, East Africa countries. Moreover, the region result implies that about 59.39, 61.0, and 49 scores far from best-performing economies in starting a business, firm establishment permit and enterprise registrations 
scores, respectively (computation is based on 100-n, for instance, $100-40.61=59.39$ where ' $n$ ' represent the value of each ease of doing business score that calculated out of 100). Additionally, it took 195 working days in the three activities on average of 19 countries in the region in 15 years. Additionally in a common, starting a business, registering property and construction permits needs to pass through at least 8 procedures at the initial stage. In contrast, Table 3 comes out with another result that, Mozambique had received about US $\$ 2.9$ billion of net FDI and it was the country at the head of East African countries from 2005-2019 based on the average of 19 countries. Additionally, as of the result in Table 3, Ethiopia, Sudan, Tanzania, and Zambia were the 2nd-5th rankings of East Africa countries of SSA concerning receiving of FDI more than UD \$1.1 billion from Global FDI share. These results supported the findings by [51] that, far from the frontier economy (distance from 100 scorers) is a suffering position and yellow light for investment growth and sustainability that needs policy alternative. More importantly, the overall mean of ease of doing business was 43.00 for 19 East Africa counties (See grand mean in Table 3). This implies that on average the countries of the region were far from the frontier economy by 57 scores.

Table 3. Ease of doing business indicators, Trade openness, CPI and FDI inflow (2005-2019).

\begin{tabular}{|c|c|c|c|c|}
\hline Country Code & $\begin{array}{l}\text { Distance from Frontier } \\
\text { (Country Level) }\end{array}$ & Trade Openness & $\begin{array}{l}\text { Corruption Perception } \\
\text { Index (Out of 100) }\end{array}$ & $\begin{array}{c}15 \text { Years Mean of FDI Inflow in } \\
\text { Billions of US \$ }\end{array}$ \\
\hline Mozambique & 45.0 & 92.35 & $25 *$ & 2.9551 \\
\hline Ethiopia ** & 44.03 & - & 38 & 1.6622 \\
\hline Sudan & 52.4 & 28.07 & $16^{*}$ & 1.5193 \\
\hline Tanzania & 45.5 & 43.59 & 38 & 1.2719 \\
\hline Zambia ** & 33.9 & 71.56 & 33 & 1.1897 \\
\hline Uganda ** & 40.0 & 41.08 & 27 * & 0.8960 \\
\hline Kenya ** & $26(3)^{+}$ & 48.31 & 31 & 0.8778 \\
\hline Madagascar & 53 & 61.489 & $25^{*}$ & 0.7014 \\
\hline MUS & $19(1)^{+}$ & 93.14 & 53 & 0.3919 \\
\hline Zimbabwe ${ }^{* *}$ & 45 & 61.56 & 24 * & 0.30016 \\
\hline Somalia & $80(1)^{-}$ & - & $12 *$ & 0.2333 \\
\hline Malawi ** & 40 & - & $30^{*}$ & 0.2317 \\
\hline Rwanda ** & $25(2)^{+}$ & 44.36 & 54 & 0.2242 \\
\hline Seychelles & 39 & 192.92 & 66 & 0.1875 \\
\hline Djibouti & 39.1 & - & 27 * & 0.1537 \\
\hline Eritrea & $79(2)^{-}$ & - & $21 *$ & 0.05262 \\
\hline Burundi ** & 55 & 39.70 & 19 * & 0.0197 \\
\hline Comoros & 53 & 38.95 & $21 *$ & 0.07593 \\
\hline South Sudan ** & $65(3)^{-}$ & - & 12 * & $(0.62226)$ \\
\hline $\begin{array}{l}19 \text { countries } \\
\text { Grand Mean }\end{array}$ & $\frac{\sum \text { all country DTF }}{19}=43$ & 51.4134 & $=\sum \frac{\text { all country CPI }}{19}=30$ & US $\$ 0.674$ \\
\hline
\end{tabular}

Source: Authors computations. ${ }^{* *}$ landlocked countries, ${ }^{*}$ Deep rooted corruption network. The lists of East African countries were according to World Population review,2021. The values plus(+) and minus (-) were indicates, increasing and decreaing in the position of the countries in distance to frointier economy (df). For instance, Kenya distance from frontiers was 26 scores, increasing and ranked 3rd position in the sample, whereas Somalia was ranked first and reducing continually from frontier economic positions

Moreover, the result in Table 3 indicated that the amount of FDI received from the global share was highest in Mozambique and negative in South Sudan on an average of 15 years. Next to South Sudan, Comoros, Burundi, and Eritrea were the countries with the low receiver of FDI, respectively, based on average data of East African countries 2005-2019. Countries such as Ethiopia, Zambia, Uganda, Kenya, Zimbabwe, Malawi, Rwanda, and Burundi are Landlocked. Although these countries are Landlocked, Ethiopia and Zambia received more than US $\$ 1$ Billion of FDI on an average of 15 years (Table 3). However, with regards to business regulations reform; Mauritius (81.5), Rwanda (76.5), and Kenya (73.2) were leading reformist 1-3 ranking from East African countries, whereas Somalia (20.0), Eritrea (21.6) and South Sudan (34.6) were at the lowest stage in simplifying their 
countries business regulations for enterprises (Table 3). Moreover, in all countries, but the deep-rooted corruption such as in South Sudan and Somalia (12/100), Burundi (19/100), Comoros and Djibouti (21/100) and others in their public system was also an issue that needs policy intervention in regulations reform in order to encourage the FDI receiving capacity (Table 3 and ${ }^{*}$ ). The highest trade openness was (192.9222) that recorded by Seychelles and the lowest (38) trade openness was observed in Sudan.

\subsection{Estimation Results and Discussions}

As already mentioned in the methodology section, this part contains results and discussion regarding selected ease of doing variables and other FDI determinants into three models. Model 1 presented the associations of inward FDI and ease of starting a business score, official times, official costs, official procedures, and minimum capital required in starting a business stage. Additionally, the effect of corruption perception index, landlocked, the interactions of country-level corruption perception index, and starting a business on inward FDI was evaluated in this Model. Likewise, Model 2 and Model 3 presented different variables result sequentially as follows (Refer Section 3.3).

Model 1 (Table 4) evaluated the effect of the first component of ease of doing business (i.e., starting a business score and its subcomponents such as, time at starting a business stage, costs required, procedures, minimum capital, corruption perception rate, landlocked, the interactions of the situations at starting a business and corruption perception in public institutions. According to the result, the association between FDI inflows and starting business score was statistically significant $(\beta=0.0674, p$-value $<0.10)$. Similarly $[46,59]$, argued that the sequential steps that starting a business should pass through have their own effect on the speed rate of FDI dynamisms. Additionally [60] added that formal procedures of doing business had a positive relationship with FDI inflow in Sub-Saharan countries. Moreover, according to the tollbooth view theory, more procedures and longer delays in time facilitate the bribe extraction and paves the way for an unofficial economy by encouraging informal sectors [61]. In a similar view, the capture view argued that the extraction of bribes at entry time discourages the multinational investment free flow. Furthermore, [10,31] argued that the O-L-I frame is a suitable situation for investment attractions. In line with the above view, in Model 1 the high rate of corruption had negatively associated $(\beta=-0.572, p$-value $<0.05)$ with multinational firms' growth across borders, whereas the interactions of starting a business and corruption perceptions were positively associated to MNEs. The result implies that when corruption perception level is high in some countries starting a business by foreign firms will inspire. Therefore, corruption sometimes helps as smoothing ground for facilitations. However, reference [43] argued that strong international laws are required for tackling the impacts of corruption against Multinational firms' expansions. Additionally [62], findings also presented the supportive view that economic informality hampers investment situations. For instance, if corruption is initiated in a single unit of business, it can contribute to half of the business loss (Model 1), [18,47,63]. The Model further indicated that the negative associations of inward FDI and landlocked at $(\beta=-0.8911, p<0.10)$. This result supports the finding by $[6,64]$. Additionally, the result further revealed that excessive bureaucracies, bribery, and corruption linked with obtaining a business license permission further impacted the hospitability of the environment for multinational enterprises to open branches or invest in SSA countries. Therefore, continuous improvements in the aforementioned barriers lead to a further reduction in the number of working days and costs involved in starting a business. Moreover, these findings supported the conclusion by [28] on the Doing Business-FDI nexus. Thus, there is ample evidence to consider the new ease-of-doing-business indicators could be more appropriate in modeling the business regulation-related policy and FDI inspiring as they are more geared towards businesses growth and sustainability. 
Table 4. Regression coefficients.

\begin{tabular}{|c|c|c|c|}
\hline Models & 1 & 2 & 3 \\
\hline \multirow{2}{*}{ Starting a business } & $0.0674^{* * *}$ & $0.0764^{* * *}$ & $0.004^{* * *}$ \\
\hline & 0.0097 & 0.00116 & 0.00457 \\
\hline \multirow{2}{*}{ Landlocked } & $-0.8911 *$ & & \\
\hline & 0.0647 & & \\
\hline \multirow{2}{*}{ Registering Property } & $0.0208^{* * *}$ & $0.0980^{* * *}$ & $1.0106^{* * *}$ \\
\hline & 0.00334 & 0.00334 & 0.0063 \\
\hline \multirow{2}{*}{ Dealing with firm's establishment permit } & $0.231^{* * *}$ & $0.123 * *$ & $0.116^{* *}$ \\
\hline & 0.0077 & 0.0158 & 0.0254 \\
\hline \multirow{2}{*}{ Trade openness } & & $0.947 *$ & \\
\hline & & 0.0518 & \\
\hline \multirow{2}{*}{ Time (in days) } & $0.0312 * * *$ & $1.0318^{* * *}$ & $3.025^{* * *}$ \\
\hline & 0.0016 & 0.0072 & 0.0087 \\
\hline \multirow{2}{*}{ Costs (in US \$) } & $-0.507^{* * *}$ & $-0.187^{* * *}$ & $2.067^{* * *}$ \\
\hline & 0.00146 & 0.0003 & 0.0031 \\
\hline \multirow{2}{*}{ Procedures (in number) } & $0.124^{* *}$ & $0.113 * *$ & $0.161^{* *}$ \\
\hline & 0.0127 & 0.0103 & 0.0138 \\
\hline \multirow{2}{*}{ Minimum capital (in US \$) } & $0.0141^{* * *}$ & & \\
\hline & 0.00817 & & \\
\hline \multirow{2}{*}{ Market size (real GDP) } & & $1.793^{* * *}$ & \\
\hline & & 0.00183 & \\
\hline \multirow{2}{*}{ Corruption level in public organization (0-100) } & $-0.572^{* *}$ & & \\
\hline & 0.0150 & & \\
\hline Starting a business * Corruption level & $0.157^{* * *}$ & & \\
\hline \multirow{2}{*}{$\begin{array}{c}\text { Registering Property * Country Market Size } \\
\text { * Corruption level }\end{array}$} & 0.0012 & 0.1812 *** & \\
\hline & & 0.00167 & \\
\hline \multirow{2}{*}{$\begin{array}{l}\text { Dealing with firm construction permit } \\
{ }^{*} \text { Corruption level }\end{array}$} & & & $7.212^{* * *}$ \\
\hline & & & 0.00145 \\
\hline \multirow{2}{*}{ Constant } & $22.196^{* * *}$ & $51.464 *$ & $34.527^{* *}$ \\
\hline & 0.0019 & 0.060 & 0.0430 \\
\hline Number of countries & 19 & 19 & 19 \\
\hline Adj. $\mathrm{R}^{2}$ & 0.491 & 0.485 & 0.3816 \\
\hline
\end{tabular}

No. of observation $=19$ countries ${ }^{*} 15$ years $=285,{ }^{* * *} p$-value $\leq 0.01$ level, ${ }^{* *} p$-Value $\leq 0.05$ level, ${ }^{*} p$-Value $\leq 0.10$ level.

In another perspective, Model 2 (Table 4) contented with measuring the effect of registering property score were positively and significantly associated to inward FDI at $\beta=0.0980, p<0.001$ and its subcomponents such as time to register firms at $\beta=1.0318$, $p<0.01$, the number of procedures it took to register firms $\beta=0.113, p<0.05$. In contrast, costs of registering property resulted in a negative association $(\beta=-0.187, p<0.01)$ with inward FDI. According to [53], the countries with shorter delay time and affordable costs of firm registration enhance a greater amount of inward FDI. This is to mean costs in realizations of firm's specific advantages for the ownership-Location-internalizations frame at registration phase had a greater impact on inward FDI [31]. In another view, when the costs of engaging in investment are becoming highest and it takes long business days to accomplish investment tasks overseas, international investors prefer switching to a better country (location) rather than growth options from within [65]. Switching from one country to another country has a material impact on the growth of one country or a region. Additionally, the predictive power of countries' market size also indicated a positive association to MNE's emerging and expansion at $\beta=1.793, p<0.001$. For instance, growing market size enhances foreign firms' attraction to obtain value from growing demand. In addition to that, when encouragements such as investment promotions tools are added to growing marketing size the number of firms registering increases. Indeed, investors engage in business to obtain an advantage of the available market demand for goods. Thus, the result revealed that in years to come, increasing market size relevance in attracting investment growth and sustainability into the region, due perhaps growing 
demand. In a similar manner, the result from trade openness shows also significant and positive associations to inward FDI at $\beta=0.947, p<0.10$. On another perspective, the interaction of registering firms' property with market size and corruption perception level together brought positive associated to inward FDI attraction in the region at $\beta=0.1812$, $p<0.001$.

Model 3 (Table 4) contains, the effects of variables evaluated against determining FDI inflow to SSA countries were dealing with construction permit scores and its subcomponents such as official times, official costs and official procedures required in dealing enterprises establishments, the interactions of dealing with construction permit and corruption status. The result implies that a single step improvement in dealing with establishing enterprises scores overseas enhance inward FDI by $\beta=0.116$ at $p<0.050$. Moreover, as delay in times for dealing with construction permits reduced by a single day inward FDI inspired by $\beta=3.025$ at $p<0.01$ and as the costs become affordable the contribution to inward FDI enhanced by $\beta=2.067$ at $p<0.01$ each. In a similar manner, as the official procedures in dealing with constructing firms abroad reduced by a single step investment attraction robust by $\beta=0.161$ at $p$-value $<0.050$. Moreover, the interaction of dealing with firm establishment and corruption level was significantly associated with new MNEs attractions. As construction permits are assisted by smoothing factors, the expansions of MNEs enhanced by $\beta=7.212$ at $p<0.010$. This means the interactions of ease of dealing with construction permit score and corruptions perception index enhances inward FDI by 7.212. Lastly, this result supported the finding of $[13,60]$.

\subsection{Conclusions and Practical Implications}

In line with previous studies similar to $[6,21,51]$ the present study came out with suitable business regulations that have positive investment responses. This research has also essentially examined the quantitative effects of the selected ease-of doing business indicators on FDI in SSA 19 countries along with landlocked, corruption perception index, market size, and trade openness. Furthermore, the findings from the analysis had also justified that the rationale for business regulations re-emphasizing most SSA economies in attracting inward FDI. Practically, reforms aimed at improving SSA country's doingbusiness scores to induce more investment growth both from private and public investors. The results additionally reflect that the ease-of-doing-business indicators certainly play an important role in attracting FDI into the sub-region too. According to empirical results, the new indicators of doing business could be appropriate in remodeling the business climate and investment attractions strategy as they are more geared towards positive responses of giant businesses to the region. However, due to the high impact of landlocked, many SSA countries needs to introduce alternative means of transportation or issue policy that assist the common usage of alternative water body from neighboring countries to enhance investment in the region. Not only the effect of landlocked but also the effect of corruption in SSA country is also much suffering that needs essential focus not deter positive response of Multinational firms to invest in the region.

In another perspective, to reduce the impacts of demotivators of investors' motives not to switch to another country from the region, investment promotion agency required to practice and inspire strategies by which structures, rules, and practices become established as legislative guidelines of investment. As cited by [66], in each country and at each level, business-relevant policies are determined in multiple policy arenas, shaped by widely differing non-market institutions, corruption conditions, and stakeholder demands for new investments. Therefore, refocusing regulations for multinational businesses can foster the economy of nations and developing markets in an endeavor to improve their presentation [40]. Official's enlargement to the importance of investment-linked institutional reform if the organization intends to increase inward FDI in their countries needs a priority. Importantly such as [67], this study finding also suggests that the assistance provided by the development aids should also emphasize countries' institutional reform in business 
regulations, growing market size, trade openness, and eliminations of corruptions to reduce unofficial costs and unfair bureaucratic circulations and time delays.

In general, the results certainly noteworthy policy conclusions for policymakers to motivate a significant amount of FDI, as well as for incorporating into their investment strategy. It means that considering business regulations reform specifically in starting a business, dealing with construction permits, and registering property certainly encourages a positive view of giant firm attractions. Additionally, the decomposed variable such as official time, procedures minimum capital, and official costs required at the starting of business needs critical emphasize not resist firms to grow and sustain in the economy. For interested researchers, it is more effective if indigenous investment sources with native approaches for business regulations reforms of Africa Policymakers embedded, particularly by considering the effects of unofficial costs, times, and procedures at starting a business, dealing in construction permits and registrations of firms.

Author Contributions: In this research work the sections of the works were shared for authors and cross validated each person's work too. Based on role distributions among authors D.B.C.; has contributed Methodology, Results, Discussions and final proof reading; C.Z.; contributed Introduction part, conclusion, literature part, conclusion and final proof reading. All authors have read and agreed to the published version of the manuscript.

Funding: This study was granted by Innovative team of Philosophy and Social Sciences in Jiangsu Higher learning institutions: Lancang-Mekong Cooperation Innovation and Risk Management under "the Belt and Road", "Grant number: 2017ZSTD002", Major Project of National Social Science Foundation of China, Grant Number: 19ZDA084; National Natural Science Foundation of China, Grant Number: 71603070.

Institutional Review Board Statement: Not applicable.

Informed Consent Statement: Not applicable.

Data Availability Statement: The data supporting reliability of the findings were embedded in the research analysis.

Acknowledgments: This research was granted by three sponsors and we would like to extend our appreciation to the sponsoring institutions. Concerning the success of this work, we would like to extend our appreciation to Hohai University Business School PhD Candidate scholars for their unreserved assistance from the beginning to end of the research work. Moreover, Changzheng and ZHU Yun deserve special thanks.

Conflicts of Interest: There is no potential source of conflict.

\section{References}

1. Ketteni, E.; Kottaridi, C. The impact of regulations on the FDI-growth nexus within the institution-based view: A nonlinear specification with varying coefficients. Int. Bus. Rev. 2019, 28, 415-427. [CrossRef]

2. Nielsen, B.B.; Asmussen, C.G.; Weatherall, C.D. The location choice of foreign direct investments: Empirical evidence and methodological challenges. J. World Bus. 2017, 52, 62-82. [CrossRef]

3. Saini, N.; Singhania, M. Determinants of FDI in developed and developing countries: A quantitative analysis using GMM. J. Econ. Stud. 2018, 45, 348-382. [CrossRef]

4. Jiang, C.X.; Yang, Q.; Li, S.; Wang, Y. Journal of international management the moderating effect of foreign direct investment intensity on local fi rms ' intangible resources investment and performance implications: A case from China. J. Int. Manag. 2011, 17, 291-302. [CrossRef]

5. Anyanwu, J.C. Promoting of investment in Africa. African Dev. Rev. 2006, 18, 42-71. [CrossRef]

6. Anyanwu, J.C. Why does foreign direct investment go where it goes?: New evidence from African countries. Ann. Econ. Financ. 2012, 13, 425-462.

7. Assane, D.; Chiang, E.P. Trade, structural reform, and institutions in Sub-Saharan African. Contemp. Econ. Policy 2012, 32, $20-29$. [CrossRef]

8. Moosa, I.A. Foreign Direct Investment: Theory, Evidence, and Practice; Springer: Berlin, Germany, 2002; Volume 40, ISBN 9781403907493.

9. Adner, R.; Levinthal, D.A. What is not a real option: Considering boundaries for the application of real options to business strategy. Acad. Manag. Rev. 2004, 29, 74-85. [CrossRef]

10. Dunning, J.H. Toward an eclectic theory of international product: Some empirical test. J. Int. Bus. Stud. 1980, 11, 9-31. [CrossRef] 
11. Radziwill, N.M. The fourth industrial revolution. Qual. Manag. J. 2018, 25, 108-109. [CrossRef]

12. Jovanovic, B.; Jovanovic, B. Ease of doing business and FDI in the ex-socialist countries. Int. Econ. Econ. Policy 2018, 15, 587-627. [CrossRef]

13. Asongu, S.A.; Odhiambo, N.M. Challenges of doing business in africa: A systematic review. J. Afr. Bus. 2019, 20, 259-268. [CrossRef]

14. Nketiah-Amponsah, E.; Sarpong, B. Ease of doing business and foreign direct investment: Case of Sub-Saharan Africa. Int. Adv. Econ. Res. 2020, 26, 209-223. [CrossRef]

15. Dwumfour, R.A. Poverty in Sub-Saharan Africa: The role of business regulations, policies and institutions. Soc. Indic. Res. 2020, 149, 1-30. [CrossRef]

16. Eifert, B.; Gelb, A.; Ramachandran, V. The cost of doing business in Africa: Evidence from enterprise survey data. World Dev. 2008, 36, 1531-1546. [CrossRef]

17. Ogbeide, F.I.; Adeboje, O.M. Effects of financial reform on business entry in sub-Saharan African countries: Do resource dependence and institutional quality matter? Afr. Dev. Rev. 2020, 32, 188-199. [CrossRef]

18. Vogiatzoglu, K. Ease of doing business and FDI inflows in ASEAN. Southeast Asian Econ. 2016, 33, 343-363. [CrossRef]

19. Mina, W. The location determinants of FDI in the GCC countries. J. Multinatl. Financ. Manag. 2007, 17, 336-348. [CrossRef]

20. Wei, Y.; Liu, X. Foreign Direct Investment in China: Determinants and Impact; Edward Elgar Publishing: Cheltenham, UK, 2001.

21. Contractor, F.J.; Nuruzzaman, N.; Dangol, R.; Raghunath, S. How FDI inflows to emerging markets are influenced by country regulatory factors: An exploratory study. J. Int. Manag. 2021, 27, 100834. [CrossRef]

22. Sharafeyeva, A.; Shepherd, B. What does "doing business" really measure? Evidence from trade times. Econ. Lett. 2020, 192, 1-3. [CrossRef]

23. Eifert, B. Do regulatory reforms stimulate investment and growth? Evidence from the doing business data, 2003-2007. SSRN Electron. J. 2011. [CrossRef]

24. Shahadan, F.; Sarmidi, T.; Jan Faizi, F. Relationships between doing business indexes and FDI net inflows: Empirical evidence from six Asian countries. Persidang. Kebangs. Ekon. Malays. 2014, 9, 609-625.

25. Borojo, D.G.; Yushi, J. The impacts of institutional quality and business environment on Chinese foreign direct investment flow to African countries. Econ. Res. Istraz. 2020, 33, 26-45. [CrossRef]

26. Estevão, J.; Lopes, J.D.; Penela, D.; Soares, J.M. The doing business ranking and the GDP. A qualitative study. J. Bus. Res. 2020, 115, 435-442. [CrossRef]

27. Arruñada, B. How doing business jeopardises institutional reform. Eur. Bus. Organ. Law Rev. 2009, 10, 555-574. [CrossRef]

28. Morris, R.; Aziz, A. Ease of doing business and FDI inflow to Sub-Saharan Africa and Asian countries. Cross Cult. Strateg. Manag. 2011, 18, 400-411. [CrossRef]

29. Hymer, S. International Operations of National Firms: A Study of Foreign Direct Investment; MIT Press: Boston, MA, USA, 1976.

30. Rugman, A.M.; Verbeke, A.; Nguyen, Q.T.K. Fifty years of international business theory and beyond. Manag. Int. Rev. 2011, 51, 755-786. [CrossRef]

31. Dunning, J.H.; Lundan, S.M. Institutions and the OLI paradigm of the multinational enterprise. Asia Pacific J. Manag. 2008, 25, 573-593. [CrossRef]

32. Dunning, J.H.; Boyden, S. The eclectic paradigm. J. Int. Bus. Stud. 1988, 19, 1-31. [CrossRef]

33. Dunning, J.H. Location and the multinational enterprise: A neglected factor? J. Int. Bus. Res. Pract. 2009, 40, 5-19. [CrossRef]

34. Contractor, F.J.; Dangol, R.; Nuruzzaman, N.; Raghunath, S. How do country regulations and business environment impact foreign direct investment (FDI) inflows? Int. Bus. Rev. 2019, 29, 1-13. [CrossRef]

35. Pajunen, K. Institutions and inflows of foreign direct investment: A fuzzy-set analysis. J. Int. Bus. Stud. 2008, 39, 652-669. [CrossRef]

36. Song, S.; Makhija, M.; Kim, S.M. International investment decisions under uncertainty: Contributions of real options theory and future directions. J. Manag. Organ. 2015, 21, 786-811. [CrossRef]

37. Li, J.; Li, Y. Flexibility versus commitment: MNEs ownership strategy in China. J. Int. Bus. Stud. 2010, 41, 1550-1571. [CrossRef]

38. Filatotchev, I.; Strange, R.; Piesse, J.; Lien, Y.C. FDI by firms from newly industrialised economies in emerging markets: Corporate governance, entry mode and location. J. Int. Bus. Stud. 2007, 38, 556-572. [CrossRef]

39. Li, J.; Rugman, A.M. Real options and the theory of foreign direct investment. Int. Bus. Rev. 2007, 16, 687-712. [CrossRef]

40. Luo, Y.; Zhao, H. Doing business in a transitional society: Economic environment and relational political strategy for multinationals. Bus. Soc. 2013, 52, 515-549. [CrossRef]

41. Kogut, B.; Kulatilaka, N. Operating flexibility, global manufacturing, and the option value of a multinational network. Manag. Sci. 1994, 40, 123-139. [CrossRef]

42. Johanson, J. Process of the internationalization development firm-a model of knowledge foreign and increasing market commitments. J. Int. Bus. Stud. 1977, 8, 23-32. [CrossRef]

43. Bahoo, S.; Alon, I.; Paltrinieri, A. Corruption in international business: A review and research agenda. Int. Bus. Rev. 2020, 29, 101660. [CrossRef]

44. Johanson, J.; Wiedersheim-Paul, F. the Internationalization of the firm-Four Swedish cases. J. Manag. Stud. 1975, 12, 305-322. [CrossRef] 
45. Brouthers, K.D. A retrospective on: Institutional, cultural and transaction cost influences on entry mode choice and performance. J. Int. Bus. Stud. 2013, 44,1-13. [CrossRef]

46. Canare, T. The effect of ease of doing business on firm creation. Ann. Econ. Financ. 2018, 19, 555-584.

47. Vučković, M.; Bobek, V.; Maček, A.; Skoko, H.; Horvat, T.; Vu Ckovi, C.A.M.; Ma Cek, A. Business environment and foreign direct investments: The case of selected European emerging economies. Econ. Res. Econ. Istazivanja 2020, 33, 243-266. [CrossRef]

48. Pinheiro-Alves, R.; Zambujal-Oliveira, J. The ease of doing business index as a tool for investment location decisions. Econ. Lett. 2012, 117, 66-70. [CrossRef]

49. Kwok, C.; Tadesse, S. The MNC as an agent of change for host-country institutions.pdf. J. Int. Bus. Stud. 2006, 37, 767-785. [CrossRef]

50. Corcoran, A.; Gillanders, R. Foreign direct investment and the ease of doing business. Rev. World Econ. 2014, 151, 103-126. [CrossRef]

51. Besley, T. Law, regulation, and the business climate: The nature and influence of the world bank doing business project. J. Econ. Perspect. 2015, 29, 99-120. [CrossRef]

52. Maričić, M.; Bulajić, M.; Radojičić, Z.; Jeremić, V. Shedding light on the doing business index: A machine learning approach. Bus. Syst. Res. 2019, 10, 73-84. [CrossRef]

53. Bayraktar, N. Foreign direct investment and investment climate. Procedia Econ. Financ. 2013, 38, 83-92. [CrossRef]

54. Wooldridge, J.M. Instructor's Solutions Manual for Econometric Analysis of Cross Section and Panel Data, 2nd ed.; MIT Press: Cambridge, MA, USA, 2011.

55. Wang, C.N.; Le, A.L. Measuring the macroeconomic performance among developed countries and Asian developing countries: Past, present, and future. Sustainability 2018, 10, 3664. [CrossRef]

56. Ghauri, P.; Grønhaug, K.; Strange, R. Research Methods in Business Studies; Cambridge University Press: Cambridge, UK, 2020; ISBN 9781108486743.

57. Nwakuya, M.T.; Ijomah, M.A. Fixed effect versus random effects modeling in a panel data analysis; A consideration of economic and political indicators in six African countries. Int. J. Stat. Appl. 2017, 7, 275-279. [CrossRef]

58. O'Brien, R.M. A caution regarding rules of thumb for variance inflation factors. Qual. Quant. 2007, 41, 673-690. [CrossRef]

59. Charoenwong, B.; Kwan, A.; Umar, T. Does regulatory jurisdiction affect the quality of investment- A dviser regulation? Am. Econ. Rev. 2019, 109, 3681-3712. [CrossRef]

60. Nangpiire, C.; Rodrigues, R.G.; Adam, I.O. Ease of doing business and foreign direct investment inflow among Sub-Sahara African countries. Int. J. Bus. Emerg. Mark. 2018, 10, 289. [CrossRef]

61. Hanousek, J.; Shamshur, A.; Svejnar, J.; Tresl, J. Corruption level and uncertainty, FDI and domestic investment. J. Int. Bus. Stud. 2021, 52, 1750-1774. [CrossRef]

62. Khavul, S.; Bruton, G.D.; Wood, E. Informal family business in Africa. Entrep. Theory Pract. 2009, 33, 1219-1238. [CrossRef]

63. Estevão, J.; Lopes, J.D.; Penela, D. The doing business ranking and the design of public policies: The effect of regional dynamics. Econ. Res. Istraz. 2021, 34, 2469-2483. [CrossRef]

64. Rjoub, H.; Aga, M.; Alrub, A.A.; Bein, M. Financial reforms and determinants of FDI: Evidence from landlocked countries in sub-Saharan Africa. Economies 2017, 5, 1. [CrossRef]

65. Ioulianou, S.P.; Leiblein, M.J.; Trigeorgis, L. Multinationality, portfolio diversification, and asymmetric MNE performance: The moderating role of real options awareness. J. Int. Bus. Stud. 2020, 52, 388-408. [CrossRef]

66. Windsor, D. Toward a global theory of cross-border and multilevel corporate political activity. Bus. Soc. 2007, 46, 253-278. [CrossRef]

67. Treviño, L.J.; Mixon, F.G. Strategic factors affecting foreign direct investment decisions by multi-national enterprises in Latin America. J. World Bus. 2004, 39, 233-243. [CrossRef] 